\title{
ANALISIS KESALAHAN EJAAN DALAM KARANGAN NARASI KARYA SISWA KELAS V SD NEGERI SUDIMARA 13 KECAMATAN CILEDUG KOTA TANGERANG
}

\author{
ANALYSIS OF SPEAKING ERRORS IN NARRATIVE COMPETITIONS BY CLASS V \\ STUDENTS OF SD NEGERI SUDIMARA 13 SUB-DISTRICTS OF CILEDUG, \\ TANGERANG CITY
}

\author{
Niken Ayu Shafira ${ }^{1}$, Enawar ${ }^{2}$, Dilla Fadhillah ${ }^{3}$, Sumiyani $^{4}$ \\ Universitas Muhammadiyah Tangerang, Kota Tangerang
}

${ }^{1}$ nikenshafira8@gmail.com, ${ }^{2}$ enawar.abah@gmail.com, ${ }^{3}$ dillafadhillah89@gmail.com

${ }^{4}$ sumiyaninitura@gmail.com

\begin{abstract}
ABSTRAK
Latar belakang penelitian ini adalah berdasarkan observasi awal yang peneliti lakukan di SD Negeri Sudimara 13 Kota Tangerang, masih terdapat kesalahan penggunaan ejaan pada karangan yang ditulis siswa kelas V SD Negeri Sudimara 13. Adapun rumusan masalah dalam penelitian ini adalah apa saja bentuk kesalahan ejaan dan kesalahan ejaan apa yang paling banyak dalam karangan narasi karya siswa kelas $\mathrm{V}$ SD Negeri Sudimara 13 . Sedangkan tujuannya adalah untuk mengetahui bentuk kesalahan ejaan dan kesalahan ejaan apa yang paling banyak dalam karangan narasi karya siswa kelas V SD Negeri Sudimara 13. Jenis penelitian deskriptif kualitatif dengan subjek penelitian adalah hasil karangan narasi siswa kelas $\mathrm{V}$ dengan jumlah 23 siswa. Teknik pengumpulan data penelitian ini melalui observasi, wawancara, dan dokumentasi. Berdasarkan pembahasan dari data hasil penelitian tentang analisis kesalahan ejaan dalam karangan narasi karya siswa kelas V di SD Negeri Sudimara 13 Kota Tangerang, maka penulis dapat berikan kesimpulan bahwa secara umum siswa kelas V SD Negeri Sudimara 13 belum menguasai penggunaan ejaan seperti huruf kapital, kata depan, dan tanda baca dalam menulis karangan narasi. Karena siswa masih kesulitan dalam memahami penggunaan ejaan.
\end{abstract}

Kata kunci: analisis kesalahan ejaan, pemakaian huruf kapital, penulisan kata depan, penggunaan tanda baca

\section{ABSTRACT}

The background of this research is based on the initial observations that the researchers made at SD Negeri Sudimara 13, Ciledug District, Tangerang City, there are still spelling errors in narrative essays written by fifth grade students at SD Negeri Sudimara 13. The formulation of the problem in this study is what forms What are the most common spelling errors and misspellings in narrative essays by fifth grade students of SD Negeri Sudimara 13. While the aim is to find out what forms of spelling errors and misspellings are most common in narrative essays by class V students of SD Negeri Sudimara 13. This type of qualitative descriptive research with research subjects is the result of narrative essays by class $V$ students with a total of 23 students. The technique of collecting data in this research is through observation, interviews, and documentation. Based on the discussion of research data on the analysis of spelling errors in narrative essays by fifth grade students at SD Negeri Sudimara 13, Ciledug District, Tangerang City, the authors can conclude that in general, fifth grade students at SD Negeri Sudimara 13 have not mastered the use of spelling such as capital letters. , prepositions, and punctuation in writing narrative essays. Because students still have difficulty in understanding the use of spelling.

Keywords: analysis of spelling errors, use of capital letters, writing of prepositions, use of punctuation 


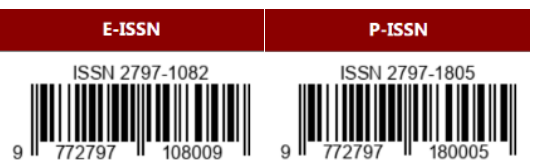

\section{PENDAHULUAN}

Pendidikan merupakan hal penting yang diperlukan oleh manusia untuk memahami dan membawa dirinya menjadi lebih baik, dengan pendidikan Allah SWT akan meningkatkan derajat manusia. Pendidikan akan menjadi sarana keselamatan manusia di dunia dan di akhirat kelak, karena dengan pendidikan manusia mendapatkan berbagai ilmu dan pengetahuan sehingga manusia dapat membedakan antara kebaikan dan keburukan. Selain itu pendidikan juga dituntut untuk membentuk manusia yang berakhlak mulia, berilmu, kreatif, mandiri, dan tanggung jawab, yang semuanya itu berdasarkan atas ketakwaan kepada Tuhan Yang Maha Esa.

Secara formal dan institusional, sekolah dasar masuk pada kategori pendidikan dasar. Pendidikan dasar menurut dalam Undang-Undang No. 20 Tahun 2003:

"Pendidikan yang berbentuk sekolah dasar atau madrasah ibtidaiyah dan sekolah menengah pertama tsanawiyah. Pendidikan dasar tersebut tidak hanya pendidikan dasar di sekolah dasar saja, tetapi juga pada sekolah menengah pertama."

Dengan kata lain, yang dimaksud dengan pendidikan dasar dalam UndangUndang tersebut adalah pendidikan wajib 9 tahun, yakni sejak sekolah dasar sampai sekolah menengah pertama, atau sejak madrasah ibtidaiyah sampai madrasah tsanawiyah. Dengan demikian sekolah dasar masuk kategori pada pendidikan dasar.

Sekolah Dasar merupakan pendidikan anak yang berusia antara 7 sampai dengan 13 tahun yang di kembangkan sesuai dengan satuan pendidikan yang diberikan kepada siswa dengan sejumlah materi atau mata pelajaran yang harus dikuasai oleh siswa, sehingga mengembangkan potensi dirinya untuk memiliki kekuatan spiritual keagamaan, pengendalian diri, kepribadian, kecerdasan, akhlak mulia, serta keterampilan yang diperlukan dirinya dan masyarakat, dalam berbangsa dan bernegara.

Dalam Sekolah Dasar sudah memakai Kurikulum 2013, kurikulum ini merupakan kurikulum tetap diterapkan oleh pemerintah untuk menggantikan Kurikulum-2006. Sehingga di kurikulum 2013 ada beberapa mata pelajaran yang bersangkutan dengan kurikulum yaitu: PPKN, Bahasa Indonesia, IPA, IPS, Matematika, Pendidikan Jasmani Olahraga dan kesehatan, dan Seni Budaya. Salah satunya adalah Mata Pelajaran Indonesia.

Pengajaran Bahasa Indonesia secara formal sudah dimulai sejak sekolah dasar. Salah satunya adalah bahwa Bahasa Indonesia berfungsi sebagai alat komunikasi yang tentu saja dapat mempengaruhi perkembangan peserta didik dalam hal pengetahuan dan keterampilan berbahasa, sehingga peserta didik dapat dengan mudah berinteraksi dan beradaptasi dengan lingkungan sosialnya. Terampil berbahasa berarti siswa dapat terampil dalam beberapa aspek yang ada dalam pembelajaran bahasa Indonesia yaitu, keterampilan menyimak, keterampilan berbicara, keterampilan membaca, dan keterampilan menulis. Keterampilan menyimak merupakan keterampilan yang paling mudah dibandingkan keterampilan berbahasa lain yaitu membaca, berbicara, dan menulis. Selain itu, siswa juga beranggapan bahwa ia akan memiliki keterampilan menyimak apabila pembelajaran bahasa yang lainnya akan berlangsung dengan baik. Keterampilan menulis dan keterampilan berbicara mempunyai kesamaan yaitu sebagai 
kegiatan produksi bahasa dan bersifat menyampaikan informasi. Kemampuan siswa dalam berbicara juga akan bermanfaat dalam kegiatan menyimak dan memahami bacaan.

Dari empat keterampilan bahasa di atas, keterampilan menulis merupakan salah satu keterampilan bahasa yang produktif, selain keterampilan berbicara. Menulis merupakan salah satu keterampilan yang dimiliki oleh siswa untuk mempertinggi kemampuan dalam membuat karangannya, keterampilan dalam mengarang ini sampai mengembangkan kerangka karangan menjadi sebuah karangan yang logis dan menggunakan kalimat yang jelas, singkat dan menarik. Di dalamnya mengandung gagasan, masalah tema yang diterapkan melalui kalimat-kalimat yang jelas, singkat, padat dan menarik. Dengan demikian, siswa dapat memahami kaidah penyusunan kalimat yang benar.

Ejaan adalah penggambaran bunyi bahasa dengan kaidah tulis menulis yang distandarisasikan yang lazim kaidah tulis menulis ini mempunyai tiga aspek yakni aspek fonologis yang menyangkut penggambaran fonem dan penyusunan abjad, aspek morfologis yang menyangkut penggambaran satuan-satuan morfemis, dan aspek sintaksis yang menyangkut ujaran berupa tanda baca.

Karangan narasi merupakan tulisan yang tujuannya menceritakan kronologis peristiwa kehidupan manusia. Oleh sebab itu karangan narasi sering juga disebut karangan cerita. Pada umumnya karangan narasi bertujuan menceritakan objek secara lengkap dan jelas dan memberikan pengalaman estetika. Sasaran karangan narasi umumnya ditunjukkan pada aspek emosi. Aspek intelektual tidak banyak digunakan dalam karangan ini. Jadi, dengan narasi diharapkan penerima dapat membentuk citra atau imajinasi.

Berdasarkan hasil observasi awal dengan wali kelas V di SD Negeri Sudimara 13 Kecamatan Ciledug Kota Tangerang, sehubungan dengan kegiatan pembelajaran Bahasa Indonesia khususnya dalam menulis karangan, masih terdapat siswa yang mengalami kesulitan pada aspek keterampilan menulis karangan narasi dengan penggunaan ejaan yang baik dan benar. Menurut guru di SD Negeri Sudimara 13 tersebut karangan yang di buat oleh siswa masih banyak terdapat kesalahan penggunaan ejaan seperti seperti pada penggunaan huruf kecil diawal kalimat, penggunaan tanda baca yang masih kurang dipahami, dan penulisan kata yang masih salah.

Berdasarkan latar belakang yang telah dikemukakan di atas, maka peneliti tertarik untuk mengambil judul "Analisis Kesalahan Ejaan dalam Karangan Narasi Karya Siswa Kelas V di SD Negeri Sudimara 13 Kecamatan Ciledug Kota Tangerang”.

\section{METODE PENELITIAN}

Pendekatan yang digunakan pada penelitian ini adalah pendekatan kualitatif. Pendekatan kualitatif digunakan berdasarkan penelitian yang berada di lapangan tentang memberikan suatu gambaran apa adanya dan tanpa adanya rekayasa yang terjadi didalam penelitian. Penelitian dilakukan pada objek yang alamiah. Peneliti yang melakukan penelitian secara kualitatif harus datang kelapangan dan mengamati serta terlibat secara intensif sampai dia menemukan secara rinci apa yang diinginkan.

Menurut Sugiyono (2019), "Penelitian kualitatif merupakan payungnya semua jenis metode pendekatan penelitian yang digunakan untuk meneliti kehidupan sosial yang 
natural/alamiah (h.361). Dalam metode ini penelitian dilakukan pada objek yang alamiah, peneliti diarahkan untuk memahami makna, menemukan hipotesis dan mengkonstruksi fenomena. Melakukan penelitian dengan metode kualitatif yaitu dengan cara ikut berperan serta dan wawancara mendalam terhadap interaksi sosial tersebut. Dengan demikian akan dapat ditemukan pola-pola hubungan yang jelas.

Jenis metode penelitian yang digunakan adalah metode penelitian kualitatif. Dalam penelitian ini peneliti berupaya untuk menganalisis kesalahan ejaan dalam karangan narasi karya siswa kelas V di SD Negeri Sudimara 13, Kecamatan Ciledug, Kota Tangerang. Oleh karena itu metode kualitatif ini dipandang sesuai untuk mengkaji dan menganalisis data secara objektif sesuai dengan data yang ditemukan pada dokumen.

Analisis data yang digunakan dalam penelitian ini berupa paparan mengenai kegiatan analisis kesalahan ejaan karangan di SD Negeri Sudimara 13 yang dilakukan oleh guru dan peserta didik. Data yang diperoleh berdasarkan dari hasil tes, observasi, wawancara, serta dokumentasi. Analisis model yang digunakan dalam penelitian ini yaitu analisis model Miles dan Huberman. Dimana analisis data itu dilakukan dengan mendasarkan diri pada penelitian di lapangan.

\section{HASIL DAN PEMBAHASAN}

Hasil penelitian yang akan disajikan adalah berupa kesalahan penulisan ejaan pada karangan narasi siswa kelas V SD Negeri Sudimara 13. Data yang terkumpul dalam penelitian kesalahan ejaan ini sebanyak 23 karangan siswa. Hasil karangan tersebut di identifikasi berdasarkan jenis kesalahannya. Jenis kesalahan ejaan tersebut dibatasi pada tiga kesalahan, yaitu kesalahan penulisan huruf kapital, kesalahan penulisan kata depan, dan kesalahan penggunaan tanda baca, selanjutnya ketiga permasalahan tersebut dirinci berdasarkan jenis kesalahan.

Kesalahan ejaan karangan narasi siswa kelas V SD Negeri Sudimara 13 Kota Tangerang, yaitu: 1) Huruf kapital berjumlah 123 kesalahan dengan jumlah presentase 52\%, 2) Kata depan $d i$ berjumlah 12 kesalahan dan kata depan ke berjumlah 4 kesalahan dengan jumlah keselurahan adalah 16 kesalahan dengan presentase $6 \%, 3$ ) Tanda baca titik (.) berjumlah 42 kesalahan, tanda baca koma (,) berjumlah 36 kesalahan, dan tanda hubung berjumlah 23 kesalahan dengan jumlah keseluruhan 101 kesalahan dengan presentase $42 \%$.

Setelah dilakukan penelitian kesalahan ejaan dalam karangan narasi, maka dapat disimpulkan bahwa siswa kelas V SD Negeri Sudimara 13 Kota tangerang masih belum sepenuhnya memahami bagaimana menulis sesuai dengan ejaan yang benar. Hal ini dapat dilihat dari banyaknya jumlah kesalahan ejaan dari setiap karangan yang dibuat oleh siswa.

\section{KESIMPULAN DAN SARAN}

Kesimpulan

Berdasarkan hasil penelitian dan pembahasan tentang Analisis Kesalahan Ejaan Karangan Narasi Karya Siswa Kelas V di SD Negeri Sudimara 13 Kota Tangerang, maka dapat disimpulkan sebagai berikut:

1. Secara umum kesalahan ejaan karangan narasi siswa kelas V SD Negeri Sudimara 13 Kota Tangerang, yaitu: 1) Huruf kapital berjumlah 123 kesalahan dengan jumlah presentase $52 \%$, 2) Kata depan $d i$ berjumlah 12 kesalahan dan kata depan ke berjumlah 4 kesalahan dengan jumlah keselurahan adalah 16 kesalahan dengan 
presentase $6 \%, 3)$ Tanda baca titik (.) berjumlah 42 kesalahan, tanda baca koma (,) berjumlah 36 kesalahan, dan tanda hubung berjumlah 23 kesalahan dengan jumlah keseluruhan 101 kesalahan dengan presentase $42 \%$.

2. Secara umum kesalahan ejaan karangan narasi siswa kelas V SD Negeri Sudimara 13 Kota Tangerang yaitu pada huruf kapital. Kesalahan huruf kapital berjumlah 123 kesalahan dengan persertase 52\%. Kesalahan pemakaian huruf kapital ini disebabkan karena kurangnya siswa untuk memahami kesalahan pemakaian huruf kapital tersebut.

\section{Saran}

Berdasarkan kesimpulan yang telah diuraikan tentang Analisis Kesalahan Ejaan dalam Karangan Narasi Karya Siswa Kelas V di SD Negeri Sudimara 13 Kecamatan Ciledug Kota Tangerang., maka peneliti memiliki beberapa saran untuk sampaikan ke beberapa pihak yaitu:

1. Bagi Peneliti

Bagi peneliti selanjutnya disarankan untuk tidak meremehkan tentang kesalahan ejaan siswa. Karena kesalahan ejaqn merupakan hal yang sangat penting dalam menulis. Diharapkan peneliti selanjutnya untuk melanjutkan penelitian tentang kesalahan ejaan siswa untuk meningkatkan siswa dalam menulis sesuai ejaan yang benar.

\section{Bagi Siswa}

Bagi siswa diharapkan mampu mengikuti pembelajaran dengan antusias dan aktif sehingga mampu menguasai materi yang diajarkan. Siswa juga hendaknya berusaha untuk meningkatkan pengetahuan mengenai ejaan, pengetahuan ini dapat diperoleh dari guru, buku-buku, dan latihan-latihan.

3. Bagi Guru

Bagi guru diharapkan dalam pembelajaran bahasa Indonesia, selalu mengingatkan kepada siswa bahwa belajar bahasa Indonesia itu sangat penting terutama dalam menulis ejaan sesuai dengan kaidah ejaan yang baik dan benar.

4. Bagi Sekolah

Bagi sekolah diharapkan untuk ikut bekerjasama dengan guru dan memberikan solusi untuk membantu siswa dalam menulis sesuai dengan kaidah penggunaan ejaan yang baik dan benar.

5. Bagi Institusi

Bagi institusi diharapkan dapat dijadikan bahan referensi tentang penggunaan ejaan agar tidak terjadi kesalahan terutama dalam menulis karangan narasi siswa.

\section{DAFTAR PUSTAKA}

Admanegara, Weda Sasmita (2017) . Pedoman Umum Ejaan Bahasa Indonesia. Yogyakarta : CV. Solusi Distribusi.

Anggi Apriliana Citra dan Avini Martini. (2018). "Analisis Kesalahan Ejaan dalam Karangan Narasi pada Siswa Kelas V Sekolah Dasar Kecamatan Sumedang Selatan”. Jurnal Pendidikan Guru Sekolah Dasar Fakultas Keguruan dan Ilmu Pendidikan Universitas Riau Vol 7, No 2.

https://primary.ejournal.unri.ac.id/index.php/ JPFKIP/article/view/6267

Anggito, Albi. Setiawan Johan (2018). Metodelogi Penelitian Kualitatif. Sukabumi: CV Jejak 
Ariani Purwo. (2018). “Analisis Kesalahan Ejaan dalam Karangan Siswa pada Mata Pelajaran Bahasa Indonesia Kelas III SDN 2 Mojoarum Kecamatan Gondang Kabupaten Tulungagung Tahun Ajaran 2018/2019” Jurnal Pena SD Vol. 05 No. 01. https://jurnal.stkippgritulungagung.ac.i d/index.php/pena-sd/article/view/1537

Dalman, H. (2018). Keterampilan Menulis. Depok: Rajawali Pers.

Fadhillah, D. Fitriani, H.S.H. (2018). Pembelajaran Bahasa Indonesia Kelas Rendah. Yogyakarta: Samudera Biru.

Fadhillah D, Hamsanah S.H dan Latifah N. (2019). Pembelajaran Bahasa Indonesia Kelas Tinggi. Yogyakarta: Samudra Biru.

Hidayat, Ahmad. (2021). Menulis Narasi Kratif Dengan Model Project Based Lerning Dan Musik Instrumental. Yogyakarta: Deepublish.

Intan Pandini. (2020). "Analisis Kesalahan Penggunaan Ejaan Yang Disempurnakan pada Karangan Narasi Siswa Kelas XI SMAN 5 Model Palu” Jurnal Bahasa dan Sastra Vol. 5, No. 4. http://jurnal.untad.ac.id/jurnal/index.ph $\mathrm{p} / \mathrm{BDS} /$ article/view/12747

Jauhari, Heri (2018). Terampil Mengarang. Bandung: Nuansa Cendekia

Kosasih, E. (2019). Dasar-Dasar Keterampilan Menulis. Bandung: CV. Yrama Widya

Mawardi (2019). Desain Penelitian Tindakan Kelas. Yogyakarta: Samudra Biru.

Mohammad Siddik (2017). "Peningkatan Pembelajaran Menulis Karangan Narasi Melalui Gambar Berseri Siswa Sekolah Dasar". Jurnal Universitas Mulawarman Vol. 27, No. 1. http://journal2.um.ac.id/index.php/sd/ar ticle/view/3187

Mustafa, Pinton setya (2020). Metodologi Penelitian Kuantitatif, Kualitatif, dan Penelitian Tindakan Kelas dalam Pendidikan Olahraga. Malang: Fakultas Ilmu Keolahragaan Unversitas Negeri Malang.

Qhadafi, Muammar Reza (2018). "Analisis Kesalahan Penulisan Ejaan yang Disempurnakan dalam Teks Negosiasi Siswa SMA Negeri 3 Palu”. Jurnal Bahasa dan Sastra Vol. 3, No. 4 http://jurnal.untad.ac.id/jurnal/index.ph p/BDS/article/view/10525

Ratri, Rose Kusumaning (2019). Cakap Berbahasa Indonesia. Yogyakarta: ArRuzz Media.

Sugiyono. (2016). Metode Penelitian Kuantitatif, Kualitatif, dan $R \& D$. Bandung: Alfabeta.

Sugiyono (2019). Metode Penelitian Pendidikan. Bandung: Alfabeta.

Sugiyono. (2020). Metode Penelitian Kualitatif. Bandung: Alfabeta.

Suprihatin, Dewi (2017). Pokok-Pokok Bahasa Indonesia. Yogyakarta: CV. Absolute Media. 